\title{
THE IMPACT OF ISLAMIC BANKING AND FINANCIAL PERFORMANCE: THE CASE OF DUBAI ISLAMIC BANK
}

\author{
Suha Jalloul
}

Lebanese American University, Lebanon

Due to the fast growth of the Muslim community, Dubai's Islamic finance industry has been also growing considerably over the last two decades. Muslim financial services may become more popular as the Muslim population expands and its living circumstances improve. The key developing market for religion-based financial products is the Middle East. This study analyzes their impact on the financial performance of Islamic banks. Data for this study was gathered from the platform www.dib.ae, the years of investigation being 2017-2020. The study's limited sample size was heavily influenced by the participants' preference for an Islamic bank over a conventional bank with an Islamic window. Because every IB operating in the GCC was included in the research, Dubai Islamic Bank is considered an excellent representation of the fully fledged Islamic banks. The researchers studied the financial performance indicators of a Dubai Islamic Bank for several years and have found that international principles are used as a guide for Sharia compliance, shareholder rights, and decision-making processes in IBs' governance and accounting standards. However, laws must be adapted to the country's specific environment in order for the bank to function properly. Managers must make sure economic competitiveness paradigm can be more easily integrated with the related Islamic values.

Keywords: Islamic banking; financial performance; Dubai banks

\section{An overview of Islamic banking and finance in Dubai}

Over the past two decades, Islamic financial sector in Dubai has expanded significantly since the Muslim population has been growing quite rapidly. As the Muslim community grows and as its living conditions are improving, Islamic finance may become more popular as an alternative to traditional financing methods. The Middle East is also a growing market for a range of other religion-based investment products, according to (Mohammed \& Muhammed, 2017).

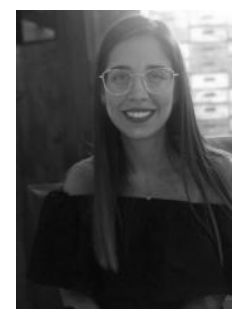

\section{Suha Jalloul}

CPA, MBA

Graduate Assistant, Department of Accounting \& Finance, Faculty of Business Administration, Lebanese American University

Research interest: Islamic banking, financial modeling, financial services, banking digitalization.

Email: suha.jalloul@lau.edu 
As part of the attempts to increase investments and obtain sustainable financing to improve economic growth, governments and financial authorities in many countries have actively promoted the establishment of Islamic financial markets. It is possible to use the asset-based nature of Islamic finance and the risk-sharing aspects of Islamic finance to better integrate Islamic finance with the real economy and improve the overall economic balance between finance and the real economy, according to (Stubing, 2017).

\section{Significance of the Study}

With the use of the yearly time series data, this study seeks to investigate the drivers behind growth rate in Islamic banking. Several econometric techniques were used by the author, including the generalized linear model and the survey-based measures.

The author relies on the statistics from the World Bank's Enterprise Survey to support his arguments. A better level of education, a more educated population, and the availability of more financial resources are all those factors that have beneficial impacts on the development of Islamic banking. However, the results also show that volatility has a negative impact on the development of Islamic banking.

The effect of economic development, a larger Muslim population, and the existence of Sharia element in the legal structure of the nation on the expansion of Islamic banking was not conclusively determined here. Regulations, tax rates, and the lack of trained labor force are the main obstacles to the development of Islamic banking.

\section{Assets Quality in the Islamic Banks of Qatar}

For economic development to continue, bank stability becomes a key factor. Due to its goal of reducing non-performing loans and non-performing financing, a segmentation plan is necessary to enhance financial stability of banks. Using Non-Performing Financing (NPF) as a proxy, this research examines the impact of segmentation on the quality of Islamic banks. Stata (version 13) and multiple regression testing have been utilized as part of a quantitative approach. Retail has a greater impact on quality of banking than wholesale, with $92.61 \%$ vs $56.05 \%$ of impact, according to the statistical results obtained by previous researchers for Qatar.

As a result, Sharia-based banks should focus on the retail sector, particularly microfinance. This will help them with preserving the quality of financing via selective financing channeling, rather than the wholesale market, as explained in (Islami, 2018).

\section{Credit risk in Islamic banking institutions in Kuwait}

Miah \& Uddin (2017) stated that there is a lot of interest in studying credit risk, and the relative credit risk of Islamic banks is still a hot topic of discussion. Several studies have attempted to address this issue by utilizing cross-country data. Such cross-country statistics should be considered with great deal of care and caution, actually, since each nation has its own growth history, geographical, economic, cultural, sociological and other peculiarities, which together result in distinct characteristics of the banking sector of each country.

Hah et al. (2017) stated that it would also be more difficult to compare data from various countries if they have distinct financial systems that may either encourage, or restrict 


\section{THE IMPACT OF ISLAMIC BANKING}

the functioning of Islamic banks. As a result, it is recommended that the variability between nations be well controlled in order to get more consistent and acceptable findings regarding credit risk.

\section{The efficiency of Sharia banks and conventional banks in terms of asset quality and stability in Bahrain in the period from 2008 to 2016}

Elsa et al. (2018) stated that Bahrain Islamic banking and conventional banking systems can and should be compared in terms of their efficiency, assets quality, and bank stability, and this is what this author performed for the time period from 2008 through 2016. Their study has relied on the secondary data obtained from Financial Service Authority Financial Statements.

By comparing Islamic banks with conventional banks in terms of efficiency, assets quality, and stability, the research has employed a descriptive approach. The author has utilized overhead cost and CIR as the efficiency proxies; non-performing loans were used as an asset quality proxy; and return on assets and Z score - as stability proxies. It was found that Islamic banking and conventional banking differ in efficiency, assets quality, and stability.

Conventional banking was shown to be more efficient, it has higher quality of assets, and is overall more stable than Sharia banking. Similar results were also obtained by (Faias \& Torres-Martinez, 2017).

\section{Data and methodology}

Our research examines various effects on Islamic banking financial performance. The time framework of our research is 2017-2020. Most data has been obtained from the official site of the bank under study — www.dib.ae.

Choosing an Islamic bank over a normal bank with an Islamic window was a major influence in our sample. When it comes to fully fledged Islamic banks, Dubai Islamic Bank is regarded to be a great representation, while every IB operating in the GCC was actually included in our study.

The research only addresses Dubai Islamic Bank in order to study its financial performance and how it manages to maintain sustainability over the period of four years, from 2017 till 2020.

The data has been extracted from the financial statements publicly available on the bank's website (mentioned above). The paper concentrates on analyzing the total income, net revenue, operating expenses, net profit, and liquidity and funding and capital adequacy of the addressed bank.

\section{Findings}

\section{Total Income}

In 2017, the total income of the Dubai Islamic Bank was AED 10,199 mln. This income increased by $15 \%$ in 2018 , thus reaching AED $11,730 \mathrm{mln}$. This increase was basically due to the evolution in Islamic financing and investments overall. In addition, the 
commission and other fees increased by $5 \%$ which also played its role in boosting the total income in 2018.

DIB maintained its strong performance and concentrated on the quality of its business in 2019 , thus leading to an $17 \%$ increase. Thus, the total income then reached AED 13,684 mln.

However, in 2020 this income decreased by 4\% and reached AED 13,142 mln due to the still ongoing pandemic which had (and still has) quite negative influences on nearly all local economic activities.

Table 1 - Income Statement Highlights

(Source: Dubai Islamic Bank Website)

\begin{tabular}{|l|c|c|c|c|}
\hline In AUD'000 & 2020 & 2019 & 2018 & 2017 \\
\hline Total Income & $13,142.00$ & $13,684.00$ & $11,730.00$ & $10,199.00$ \\
\hline $\begin{array}{l}\text { Depositors'Sukuk holders share of } \\
\text { profit }\end{array}$ & $(3,672.00)$ & $(4,418.00)$ & $(3,528.00)$ & $(2,512.00)$ \\
\hline Net Operating Revenue & $9,470.00$ & $9,266.00$ & $8,202.00$ & $7,687.00$ \\
\hline Operating Expenses & $(2,728.00)$ & $(2,358.00)$ & $(2,322.00)$ & $(2,336.00)$ \\
\hline $\begin{array}{l}\text { Profit before impairment losses } \\
\text { and income taxes }\end{array}$ & $6,743.00$ & $6,908.00$ & $5,880.00$ & $5,351.00$ \\
\hline Impairment Losses & $(4,552.00)$ & $(1,764.00)$ & $(833.00)$ & $(823.00)$ \\
\hline Gain on Bargain Purchase & $1,015.00$ & - & - & - \\
\hline Income taxes & $(46.00)$ & $(42.00)$ & $(43.00)$ & $(24.00)$ \\
\hline Net Profit for the period & $3,160.00$ & $5,103.00$ & $5,004.00$ & $4,504.00$ \\
\hline Key Ratios & 2020 & 2019 & 2018 & 2017 \\
\hline Net Profit Margin, \% & $2.61 \%$ & $3.15 \%$ & $3.14 \%$ & $3.11 \%$ \\
\hline Cost to Income Ratio, \% & $29.40 \%$ & $26.90 \%$ & $28.30 \%$ & $30.40 \%$ \\
\hline Return on Average Assets, \% & $1.22 \%$ & $2.25 \%$ & $2.32 \%$ & $2.34 \%$ \\
\hline Return on Average Equity, \% & $10.40 \%$ & $17.10 \%$ & $18.10 \%$ & $18.70 \%$ \\
\hline
\end{tabular}

\section{Net Revenue}

Net revenue increased by 6.7\%: it used to be AED 7,687 mln back in 2017, and then it reached AED 8,202 mln in 2018. Moreover, DIB also showed an increase by $13 \%$ in net revenue in 2019 (reached AED 9,267 mln). In 2020, there was a slight increase by $2 \%$ in net revenues which in that year reached AED $9471 \mathrm{mln}$. This was supported by the reduction in funding costs during the said year.

Income was also boosted by $11 \%$ increase in commission and fees which amounted to AED 1,646 mln in 2020.

\section{Operating Expenses}

DIB showed a slight reduction in its operating expenses - from AED 2,336 mln in 2017 to AED 2,322 $\mathrm{mln}$ in 2018. This has led to a significant improvement in cost to income ratio which reached $28.3 \%$ as compared to $30.4 \%$ back in 2017 .

However, in 2019 this amount increased to become rather stable at AED 2,358 mln and then showed a huge increase (by as many as 16\%) and reached AED 2,728 mln in 2020. This 


\section{THE IMPACT OF ISLAMIC BANKING}

increase in operating expenses can be explained by additional expenses incurred due to the acquisition of Noor Bank at the beginning of 2020. As a result, cost to income ratio increased by 250 bps, from $26.9 \%$ in 2019 to $29.4 \%$ in 2020 .

\section{Net Profit}

DIB showed a huge increase in its net profits in 2018 which amounted to AED 5,004 mln as compared to AED 4,504 mln in 2017. This $11 \%$ increase was due to the vast growth and improvements in the bank's business that lead to a significant rise in its top line income as well as enhanced management control which, in its turn, has led to optimized management of costs.

Moreover, DIB continued to improve its performance and thus its net profit grew even more in 2019, reaching AED 5,103mln . As a result, net profit margin increased by $3.15 \%$. ROA and ROE also improved to reach $2.25 \%$ and $17.1 \%$ respectively (also in 2019).

However, serious changes in both global and domestic economic activities due to the pandemic forced many banks to be taking a more prudent approach to provisioning. In the case of DIB, this led to a $38 \%$ decline in the net profits of the bank which then reached AED $3,160 \mathrm{mln}$ in 2020 .

Improvements on the balance sheet through the strategic shift towards lower risk sectors is expected to provide a more sustainable income and revenue stream for the bank in the succeeding quarters.

Total Income (AED mn)

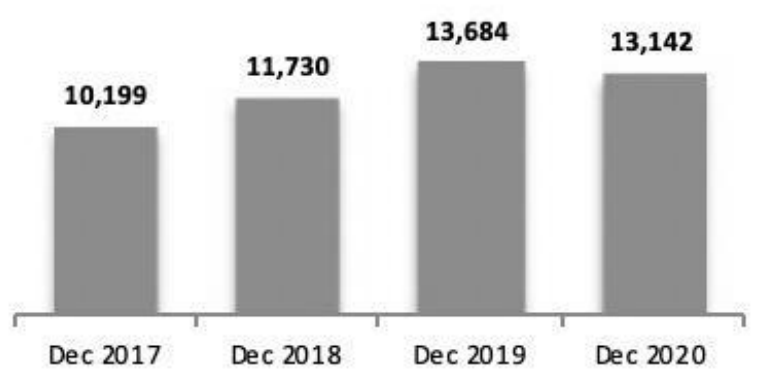

Net Operating Revenue (AED mn)

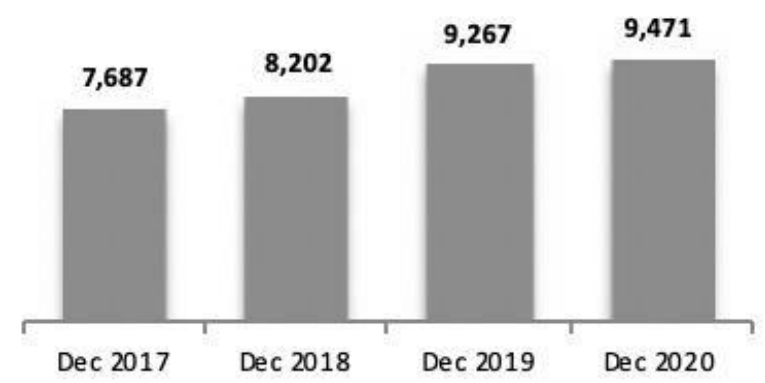

Figure 1 - Total Income and Net Operating Revenue of DIB (Source: Dubai Islamic Bank official website)

\section{Net Financing \& Sukuk Investments}

Referring to core business indicators, net financing \& Sukuk investments showed an increase by $11.8 \%$, from AED 157.4 bln to AED 175.9 bln at the end of 2018. This account also increased by 5\% in 2019 to reach AED 184.2 bln .

Realignment of the strategy focusing on lower risk sectors, particularly sovereigns, and gross new consumer financing of nearly AED 13 bln continues to be the key driver of the bank's growth during 2020. As a result, the net financing \& Sukuk investments grew to AED 232.0 bln by the end of 2020 , a robust rise of $26 \%$. 
Table 2 - Financial Position Highlights

(Source: Dubai Islamic Bank's official website)

\begin{tabular}{|l|c|c|c|c|}
\hline \multicolumn{1}{|c|}{ AED'000 } & 2020 & 2019 & 2018 & 2017 \\
\hline $\begin{array}{l}\text { Net Financing \& Sukuk } \\
\text { Investment }\end{array}$ & $232,044.00$ & $184,157.00$ & $175,917.00$ & $157,357.00$ \\
\hline Interbank placement \& CDs & $23,949.00$ & $16,275.00$ & $21,311.00$ & $23,681.00$ \\
\hline $\begin{array}{l}\text { Equities \& Properties } \\
\text { Investments }\end{array}$ & $10,388.00$ & $9,788.00$ & $9,560.00$ & $8,942.00$ \\
\hline Cash \& Other Assets & $23,176.00$ & $21,576.00$ & $16,894.00$ & $17,357.00$ \\
\hline Total Assets & $289,557.00$ & $231,796.00$ & $223,682.00$ & $207,337.00$ \\
\hline Customers' Deposits & $205,925.00$ & $164,418.00$ & $155,657.00$ & $147,181.00$ \\
\hline Sukuk Financing Instruments & $18,744.00$ & $14,852.00$ & $12,371.00$ & $8,659.00$ \\
\hline Total Liabilities & $246,426.00$ & $197,064.00$ & $189,556.00$ & $178,456.00$ \\
\hline Shareholder Equity \& Reserve & $28,606.00$ & $25,565.00$ & $24,118.00$ & $18,592.00$ \\
\hline Tier 1 Sukuk & $11,937.00$ & $6,428.00$ & $7,346.00$ & $7,346.00$ \\
\hline Non-controlling Interest & $2,587.00$ & $2,739.00$ & $2,663.00$ & $2,943.00$ \\
\hline Total Liabilities \& Equity & $289,557.00$ & $231,796.00$ & $223,682.00$ & $207,337.00$ \\
\hline Key Ratios & 2020 & 2019 & 2018 & 2017 \\
\hline $\begin{array}{l}\text { Net Financing to Customer } \\
\text { Deposit }\end{array}$ & $96 \%$ & $91.8 \%$ & $93.0 \%$ & $90.6 \%$ \\
\hline CET 1 Ratio & $12 \%$ & $12 \%$ & $12.4 \%$ & $11.5 \%$ \\
\hline CAR & $5.7 \%$ & $3.9 \%$ & $3.4 \%$ & $3.4 \%$ \\
\hline NPF Ratio & $76 \%$ & $101 \%$ & $112.0 \%$ & $117.9 \%$ \\
\hline Coverage Ratio & & $16.5 \%$ & $17.5 \%$ & $17.2 \%$ \\
\hline
\end{tabular}

\section{Total Assets}

Total assets of the bank in question amounted to AED 223.7 bln in 2018, after an $7.9 \%$ increase from AED 207.3 bln in 2017. In 2019, the total assets grew even more to reach AED 231.8 bln.

Despite headwinds giving a clear display of the bank's ability to discover business opportunities through its well-structured franchise, DIB's total assets increased by $25 \%$ to reach AED 289.6 bln in 2020.

\section{Asset Quality}

Non-performing financing ratio (NPF) was 3.4\% in 2018 whereas impaired financing ratio was 3.3\%. In 2019, NPF ratio and impaired financing ratio both increased to $3.94 \%$ and $3.89 \%$ respectively. This ratio also rose in 2020 to reach $5.7 \%$.

Cash coverage ratio at the end of 2018 amounted to $112 \%$ while the overall coverage ratio reached $150 \%$, taking into consideration the risk cost of 55 bps. In 2019, the cash 


\section{THE IMPACT OF ISLAMIC BANKING}

coverage ratio as well as the overall coverage ratio decreased to $101 \%$ and $135 \%$ respectively, while the risk cost amounted to $87 \mathrm{bps}$.

Even though the general market showed an increase in NPFs during the year 2020, the cash coverage ratio and the overall coverage now stands at $76 \%$ and $104 \%$ respectively because of unstable conditions. Normalized cost of risk for the period was $137 \mathrm{bps}$ (excluding one-off charges).

\section{Liquidity and funding}

Customer deposits back in 2017 amounted to AED 147 bln. These deposits increased by $6 \%$ in 2018 to reach AED 156 bln while CASA deposits increased to AED 54 bln due to maintaining payroll and other operating activities. As a result, financing to deposit ratio stood at 93\%. At the end of 2019, customer deposits increased to AED 164 bln after an 6\% increase, and CASA deposits slightly increased to AED 54.6 bln which also represent $33 \%$ of the customer deposits. Financing to deposit ratio decreased by $1 \%$ to become $92 \%$.

Customer deposits grew to AED 205.9 bln in 2020, thus reflecting a strong rise of $25 \%$. CASA rose strongly by $58 \%$ to reach AED 86.2 bln, growing from AED 54.6 bln at the end of the 2019 year. This currently represents about $42 \%$ of customer deposits. Net financing to deposit ratio stood at $96 \%$, signifying ample liquidity despite material growth in financing books. Liquidity coverage ratio (LCR) is at $129 \%$, thus being currently well above the minimum requirement set by the UAE Central Bank (70\%) as part of the TESS program.

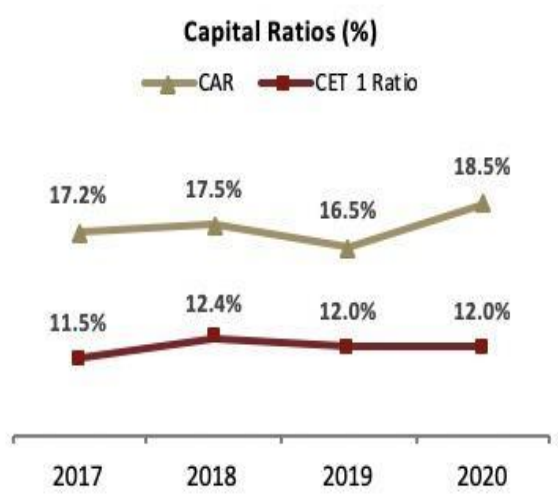

Figure 2 - Capital Adequacy Ratios of DIB

(Source: Dubai Islamic Bank's official website)

Capitalization plays a crucial role in boosting business growth. Capital adequacy ratio (CAR) was at $17.5 \%$ in 2017 which is greater than the minimum requirement $12.75 \%$, whereas CET1 was $12.4 \%$ as compared to the minimum requirement of $9.25 \%$, implying a substantial growth under new Basel Three.

As of the end of 2018, the Capital Adequacy Ratio and CET 1 ratios were at $17.5 \%$ and $12.4 \%$, respectively. Success in issuing rights bolstered the bank's basic capital, as the rights offer generated significant interest among a diverse group of local and foreign investors. Next year, capital adequacy ratios remained at $16.5 \%$ and $12.0 \%$ respectively (against the minimum CAR requirement of $13.5 \%$ ). The bank was then also recognized by the regulator 
as the domestic systemically important bank (D-SIB), thus indicating the significance of DIB's franchise for the whole country's financial industry. The capital adequacy ratio increased to $18.5 \%$ (+200 basis points) in 2020, while the CET 1 ratio remained at $12 \%$. In spite of the year's significant growth, capital levels have remained stable and far over the minimal statutory requirements.

In 2017, Return on Assets and Return on Equity were $2.32 \%$ and $18.1 \%$ respectively. These ratios improved to reach $2.25 \%$ and $17.1 \%$ respectively in 2019 . Besides the circumstances related to focusing on shareholders returns of the bank, ROE remained to be at $10.4 \%$ in 2020 .

\section{Limitations}

The present research has certain drawbacks. The main obstacle in the course of our investigation has been the lack of access to previous financial statements for the bank in question. As a result of using restricted variables and the fact that its scope is confined to the GCC nations, the study has certain limitations.

Also, the article has addressed only one bank which is Dubai Islamic Bank. For future studies in the similar directions, it is suggested to take two Islamic Banks and also two traditional commercial banks and then compare their ratios.

\section{Recommendations and Future Contribution}

To be explored further is a comparative study of IBs in the GCC and MENA. After a thorough assessment of the results, this paper's conclusions may be relevant to the IBs regulators' management as well.

When it comes to Sharia compliance, shareholder rights, or decision-making processes in IBs' governance and accounting standards, international principles should be used as a reference, but laws need to be adapted to the country-specific environment too. A paradigm that combines Islamic principles with economic competitiveness must be taught for all related managers.

The business model under consideration has to be continually improved by creating ad hoc committees that are comprised of the members of government, corporate standard setting organizations, and other interested parties.

In addition, liquidity management has always been a major roadblock in the development course of IBs in the past. Extending financial arms to reach unbanked areas as well as expanding the variety of IBs products to attract consumers who would otherwise depend on traditional banking products, may help alleviate this problem, at least partially.

There must be clear definitions for the permissibility of IB practices to reduce complexity and ambiguity that now exists in this framework. In order to stay competitive, it is highly suggested that Islamic banks provide new solutions that are fundamentally different from the traditional banking services and commodities that cater to untapped population segments.

On a final note, as GCC financial operations begin to diversify, continuous innovations must be integrated into Sharia-compliant financial activities. This will allow for a wider range of opportunities for sustainable IBs development. 


\section{THE IMPACT OF ISLAMIC BANKING}

\section{References}

Elsa, E., Utami, W. \& Nugroho, L. (2018). A Comparison of Sharia Banks and Conventional Banks in Terms of Efficiency, Asset Quality and Stability in Indonesia for the Period 2008-2016. International Journal of Commerce and Finance, 4(1): 134-149.

Faias, M. \& Torres-Martínez, J. P. (2017). Credit market segmentation, essentiality of commodities, and supermodularity. Journal of Mathematical Economics, 70: 115-122.

Hah, P. Q., Baloch, M. A., Tahir, M. \& Ali, A. (2017). Multi-dimensional financial analysis of Islamic and conventional banks of Pakistan. A comparative study of Meezan and NIB bank. Journal of Managerial Sciences, IX(2).

Islami, B. (2018). About us. Available online at: https://bankislami.com.pk/about-us.

Meezan Bank (2012). Annual Report. Available online at: www.meezanbank.com/wpcontent/themes/mbl/downloads/annualreport2012.pdf

Miah, M. D. \& Uddin, H. (2017). Efficiency and stability: A comparative study between islamic and conventional banks in GCC countries. Future Business Journal, 3(2): 172-185.

Mohammed, S.A. \& Muhammed, D.J. (2017). Financial crisis, legal origin, economic status and multi-bank performance indicators: evidence from Islamic banks in developing countries", Journal of Applied Accounting Research, 18(2): 208-222.

Stubing, D. (2017). Islamic banking: Challenge to maintain leading growth in a competitive market, Forbes Middle East, Dubai. Available online at: https://www.forbesmiddleeast.com/islamicbankingchallenge-\%20to-maintain-leading-growth-in-a-competitive-market.

Paper submitted

Paper accepted for publishing

Paper published online
29 May 2021

21 July 2021

30 September 2021 


\section{Appendix}

Table 3- Net Income. Consolidated Statements of Profit or Loss (Source: Dubai Islamic Bank's official website)

\begin{tabular}{|c|c|c|c|c|}
\hline AED'000 & 2020 & 2019 & 2018 & 2017 \\
\hline $\begin{array}{l}\text { Income from Islamic financing and } \\
\text { investing transactions }\end{array}$ & $10,370,351.00$ & $10,723,145.00$ & $9,481,215.00$ & $7,794,582.00$ \\
\hline $\begin{array}{l}\text { Commission fees, and foreign exchange } \\
\text { income }\end{array}$ & $1,645,616.00$ & $1,482,606.00$ & $1,475,949.00$ & $1,406,507.00$ \\
\hline $\begin{array}{l}\text { Income from other investments at fair } \\
\text { value }\end{array}$ & $50,661.00$ & $65,660.00$ & $45,085.00$ & $31,038.00$ \\
\hline $\begin{array}{l}\text { Income from properties held for } \\
\text { development and sale, net }\end{array}$ & $53,693.00$ & $126,011.00$ & $123,804.00$ & $196,629.00$ \\
\hline Income from investment properties & $83,287.00$ & $294,955.00$ & $155,522.00$ & $118,637.00$ \\
\hline $\begin{array}{l}\text { Share of profit from associates and joint } \\
\text { ventures }\end{array}$ & $20,141.00$ & $58,355.00$ & $137,496.00$ & $122,050.00$ \\
\hline Other income & $918,582.00$ & $933,623.00$ & $310,691.00$ & $529,342.00$ \\
\hline Total Income & $13,142,331.00$ & $13,684,355.00$ & $11,729,762.00$ & $10,198,785.00$ \\
\hline $\begin{array}{l}\text { Less depositors' and sukuk holders' share } \\
\text { of profit }\end{array}$ & $(3,671,626.00)$ & $(4,417,563.00)$ & $\begin{array}{c}(3,528,057.00 \\
)\end{array}$ & $(2,511,671.00)$ \\
\hline Net Income & $9,470,705.00$ & $9,266,792.00$ & $8,201,705.00$ & 7,687,114.00 \\
\hline \multicolumn{5}{|l|}{ Operating Expenses } \\
\hline Personnel expenses & $(1,699,532.00)$ & $(1,586,883.00)$ & $1,580,496.00$ & $(1,568,090.00)$ \\
\hline General \& administrative expenses & $(837,682.00)$ & $(632,391.00)$ & $(607,804.00)$ & $(602,378.00)$ \\
\hline Depreciation of investment properties & $(56,678.00)$ & $(36,960.00)$ & $(35,148.00)$ & $(45,723.00)$ \\
\hline Depreciation of property \& equipment & $(134,028.00)$ & $(102,180.00)$ & $(98,554.00)$ & $(119,451.00)$ \\
\hline Total Operating Expenses & $(2,727,920.00)$ & $(2,358,414.00)$ & $2,322,002.00$ & $(2,335,642.00)$ \\
\hline $\begin{array}{l}\text { Net operating income before net } \\
\text { impairment charges and taxation }\end{array}$ & $6,742,785.00$ & $6,908,378.00$ & $5,879,703.00$ & $5,351,472.00$ \\
\hline Impairment charges, net & $(4,551,689.00)$ & $(1,763,501.00)$ & $(833,471.00)$ & $(823,453.00)$ \\
\hline Gain on bargain purchase & $1,014,654.00$ & - & - & - \\
\hline $\begin{array}{l}\text { Profit for the year before income tax } \\
\text { expense }\end{array}$ & $3,205,750.00$ & $5,144,877.00$ & $5,046,232.00$ & 4,528,019.00 \\
\hline Income Tax expense & $(46,063.00)$ & $(42,266.00)$ & $(42,414.00)$ & $(24,439.00)$ \\
\hline Net Profit for the year & $3,159,687.00$ & $5,102,611.00$ & $5,003,818.00$ & 4,503,580.00 \\
\hline
\end{tabular}




\section{THE IMPACT OF ISLAMIC BANKING}

Table 4 - Net Profit. Consolidated Statement of Comprehensive Income

(Source: Dubai Islamic Bank's official website)

\begin{tabular}{|l|c|c|c|c|}
\hline AED'000 & $\mathbf{2 0 2 0}$ & $\mathbf{2 0 1 9}$ & $\mathbf{2 0 1 8}$ & $\mathbf{2 0 1 7}$ \\
\hline Net profit for the year & $\mathbf{3 , 1 5 9 , 6 8 7 . 0 0}$ & $\mathbf{5 , 1 0 2 , 6 1 1 . 0 0}$ & $\mathbf{5 , 0 0 3 , 8 1 8 . 0 0}$ & $\mathbf{4 , 5 0 3 , 5 8 0 . 0 0}$ \\
\hline other comprehensive income/loss items & & & & \\
\hline $\begin{array}{l}\text { items that may be reclassified subsequently } \\
\text { to profit or loss }\end{array}$ & & & & \\
\hline $\begin{array}{l}\text { Exchange differences on translation of foreign } \\
\text { operations, net }\end{array}$ & $(81,962.00)$ & $(43,230.00)$ & $(566,900.00)$ & $(21,841.00)$ \\
\hline Fair value gain on Sukuk investment & $3,164.00$ & - & - & \\
\hline $\begin{array}{l}\text { items that will not be reclassified } \\
\text { subsequently to profit or loss }\end{array}$ & & & & \\
\hline $\begin{array}{l}\text { Fair value (loss) income on other investments } \\
\text { carried at FVTOCI, Net }\end{array}$ & $(317,913.00)$ & $(414,888.00)$ & $(236,091.00)$ & $134,942.00$ \\
\hline $\begin{array}{l}\text { other comprehensive income/loss for the } \\
\text { year }\end{array}$ & $\mathbf{( 3 9 6 , 7 1 1 . 0 0 )}$ & $\mathbf{( 4 5 8 , 1 1 8 . 0 0 )}$ & $\mathbf{( 8 0 2 , 9 9 1 . 0 0 )}$ & $\mathbf{1 1 3 , 1 0 1 . 0 0}$ \\
\hline Total comprehensive income for the year & $\mathbf{2 , 7 6 2 , 9 7 6 . 0 0}$ & $\mathbf{4 , 6 4 4 , 4 9 3 . 0 0}$ & $\mathbf{4 , 2 0 0 , 8 2 7 . 0 0}$ & $\mathbf{4 , 6 1 6 , 6 8 1 . 0 0}$ \\
\hline
\end{tabular}

